\title{
Azerbaycan Demokratik Cumhuriyeti (ADR) Dış Politiikası ve Ali Merdan Topçubaşı
}

\section{Foreign Policy of Azerbaijan Democratic Republic (ADR) and Ali Merdan Topchibashi}

\author{
Vügar İmanbeyli ${ }^{1}$
}

'Sorumlu yazar/Corresponding author: Vügar İmanbeyli (Doç. Dr.),

İstanbul, Türkiye.

E-posta: vugarimanbeyli@sehir.edu.tr ORCID: 0000-0001-8053-3381

Başvuru/Submitted: 11.05 .2020

Kabul/Accepted: 15.07 .2020

Atıf/Citation: Imanbeyli, Vugar. "Azerbaycan Demokratik Cumhuriyeti (ADR) Dıș Politikası ve Ali Merdan Topçubaşı.,' Avrasya Incelemeleri Dergisi - Journal of Eurasian Inquiries 9, 2 (2020): 227-245

https://doi.org/10.26650/jes.2020.015

\section{ÖZ}

1918-1920 yılları arasında 23 ay gibi kısa bir sürede varlığını sürdüren Azerbaycan Demokratik Cumhuriyeti (ADR), çağdaş (kuzey) Azerbaycan tarihinin son derece önemli bir aşamasını oluşturmaktadır. Şimdiye dek bu dönemle ilgili azımsanmayacak miktarda belge yayınları ile birlikte bu dönemin farklı yönlerini ortaya koyan incelemeler yapılmıştır. Bununla birlikte, milli tarihçiler tarafından yapılan ve kıymeti tartışılmaz araştırmalardaki kronolojik-tarihi (ve biraz da deskriptif) yaklaşımlardan ziyade bu kısa tecrübeyi, Uluslararası Illişkiler disiplininin sunduğu imkanlar doğrultusunda, özellikle de ADR'in işgalinin yüzüncü yılında değerlendirmekte fayda vardır. Bu tür bir değerlendirme, mevcut bilgi birikimine ve ayrıca ADR tecrübesinin daha iyi anlamlandırılmasına katkı sağlayacaktır. Bu yazı böyle bir değerlendirmeye giriş mahiyetinde olup bazı sınıflandırmalar denemesini ve mülahazaları ifade etmek amacıyla kaleme alınmıştır. Bazı tasnifler dışında yazının geliştirmeye çalıştığı ana fikir, her ne kadar bir devlet tecrübesine tam olarak sahip olmasalar da ADR kurucu kadrolarının dış politikada dönemin şartlarının gerektirdiği çevikliği çok çabuk edindikleri, dış politika ve diplomaside kurumsallaşmayı önceledikleri, devletin bağımsızlığının tanınması yolunda neredeyse tüm diplomasi araçlarını kullanmaya çalıştıkları hususudur. Tüm bunların da ADR'in "baş diplomatı" payesini ziyadesiyle hak eden Ali Merdan Topçubaşı́nın (1865-1934) diplomatik eylem ve söylemlerine yansıdığı görülmektedir.

Anahtar kelimeler: Azerbaycan, Dış politika, Azerbaycan Demokratik Cumhuriyeti (ADR), Diplomasi

\section{ABSTRACT}

The Azerbaijani Democratic Republic (ADR), which existed for only 23 months between 1918 and 1920, occupies an extremely important place in the history of contemporary (Northern) Azerbaijan. So far a considerable amount of works including archival documents as well as academic studies investigating different aspects of this period have been produced. However, accepting the importance of chronological-historical (and partly descriptive) works made by national historians, this short experience should also be evaluated by using methods that the International Relations discipline presents. This kind of assessment, that 
would be especially meaningful in the centenary of its fall, will contribute to our understanding of the ADR experience. This article has been written as an introduction to such an assessment and includes some initial classifications and generalizations. Alongside this, the main idea that it tries to develop is that the ADR's founders, though lacking state management experience, were able to quickly acquire capabilities that were necessary to conduct foreign policy in that time, gave priority to institutionalization in foreign policy and diplomacy, and used almost all diplomatic instruments in order to make the state independence recognized. All of this, it can be said, was reflected in the diplomatic discourse and activities of Ali Merdan Topchubashi (1865-1934), who rightly deserves to be called the "chief diplomat" of the ADR.

Keywords: Azerbaijan, Foreign policy, the Azerbaijani Democratic Republic, Diplomacy

\section{EXTENDED ABSTRACT}

The Azerbaijani Democratic Republic (ADR), which existed for only 23 months between 1918 and 1920, occupies an extremely important place in the history of contemporary (Northern) Azerbaijan. So far a considerable amount of works including archival documents as well as academic studies investigating different aspects of this period has been produced. However, accepting the importance of chronological-historical (and partly descriptive) works made by national historians, this short experience should also be evaluated by using methods that the International Relations discipline presents. This kind of assessment, that would be especially meaningful in the centenary of its fall, will contribute to our understanding of the ADR experience. This article has been written as an introduction to such an assessment and includes some initial classifications and generalizations. The article is composed of three parts.

In the first part, the article identifies the general framework for the ADR foreign policy under three subtitles, namely, parameters, threats and periodization. In this sense, it classifies the following five fundamental parameters as shaping the ADR foreign policy: 1) de facto and de jure recognition of the state independence, 2) guaranteeing the general security and security of borders, 3 ) the search for allies (especially among great powers), 4) establishing political/economic/trade relations with neighbors and other states, 5) promotion of the idea of the Caucasian Confederation. Subsequently, the article identifies the following four main threats that threatened the existence and security of ADR: 1) the Baku Bolshevik Commune, 2) General Denikin's Voluntary Army, 3) Violent tension with Armenia and local war in the borderland, 4) the Bolshevik Russia. The ADR somehow overcame the first two threats, tried to keep the third one under control, but failed to challenge the last. The article also divides the ADR foreign policy process into three periods: 1) (full) protection by the Ottoman state, 2) (semi) protection by Britain, 3) a period without protection (de facto independence).

In addition to these classifications, in the second part, the article deals with the practical side of ADR foreign policy, that is, bilateral relations with neighbors and regional and great powers and tries to summarize a general framework of policies and contacts. It seems that in a short time the ADR not only achieved the establishment of formal relations in all these levels, 
but also developed multidimensional (political, economic, military etc.) foreign engagement. Moreover, the article touches on some aspects on conduction of diplomacy by the ADR, that is, principles, instruments and institutionalization of diplomacy. It concludes that in a short period of time, the ADR founders tried to institutionalize diplomacy and to build an effective ministry having central apparatus and $a d$ hoc as well as resident missions abroad. The ADR demonstrated all characteristics of a small state by focusing on multilateral diplomacy, integration with neighbors as well as defending principles of peaceful co-existence. The main idea that this article tries to develop here is that the ADR's founders, though lacking state management experience, were able to quickly acquire capabilities that were necessary to conduct foreign policy in that time, gave priority to institutionalization in foreign policy and diplomacy, and used almost all diplomatic instruments in order to make the state independence recognized.

All of this, it can be said, was reflected on the diplomatic discourse and activities of Ali Merdan Topchubashi (1865-1934), who rightly deserves to be called the "chief diplomat" of ADR. In the last part, the article briefly illustrates Topchubashi's diplomatic activities in Istanbul and Paris, and presents him as a zenith of ADR diplomacy. 


\section{Giriş}

1918-1920 yılları arasında 23 ay gibi kısa bir sürede varlığını sürdüren Azerbaycan Demokratik Cumhuriyeti (orijinal ifadesiyle, Azerbaycan Demokratik Respublikasl-ADR) ${ }^{1}$, çağdaş (kuzey) Azerbaycan tarihinin son derece önemli bir aşamasını oluşturmaktadır. Şimdiye dek bu dönemle ilgili azımsanmayacak miktarda belge yayınları ile birlikte ADR tecrübesinin farklı (siyasi, ekonomik, sosyal vs.) yönlerini ortaya koymaya çalışan incelemeler yapılmıştır. ${ }^{2}$ Bununla birlikte, üzerinden yüz yıllık bir sürenin geçmesinin ardından milli tarihçiler tarafından yapılan ve kıymeti tartışılmaz araştırmalardaki kronolojik-tarihi (ve biraz da deskriptif) yaklaşımlardan ziyade ADR döneminin dış politika ve diplomasisinin Uluslararası İlişkiler biliminin sunduğu imkanlar doğrultusunda ve mevcut bilgi birikimi çerçevesinde değerlendirilmesine gerek duyulmaktadır. Bu tür bir değerlendirmenin, mevcut bilgi birikimimize ve ayrıca ADR tecrübesini daha iyi anlamlandırmaya katkı sağlayacağ belirtilmelidir. Bu yazı böyle bir değerlendirmeye giriş mahiyetinde olup bazı sınıflandırmalar denemesini ve mülahazaları ifade etmek amacıyla kaleme alınmıştır.

Yazı, üç kısımdan oluşmaktadır. Birinci olarak ADR politikasının genel çerçevesi ele alınacaktır. Burada dış politikanın başlıca parametreleri ve belli başlı aşamaları tasnif edilecek, karşılaşılan çeşitli dış tehditlere değinilecektir. İkinci olarak ADR dış politikasının pratik düzlemdeki çerçevesinden bahsedilecektir. Burada bölgesel ve uluslararası düzeydeki ilişkilere kısaca yer verilecektir. Ayrıca, bu kısımda ADR diplomasisinin bir takım bileşenleri ayırt edilmeye çalışılacak ve bu diplomasinin prensipleri, kurumsal gelişimi ve araçları özetle sözkonusu edilecektir. Üçüncü olarak ise, tüm bu diş politika ve diplomasi süreçlerinin tam merkezinde bulunarak dış politikanın hem yapımcısı, hem de uygulayıcısı olarak temayüz eden Ali Merdan Topçubaşı (1865-1934) mevzubahis edilecektir. ADR'in “baş diplomatı"

1 Bu yazıda neden ADR kısaltmasının kullanıldı̆̆ını kısaca açıklığa kavuşturmak gerekir. Mevcut literatürde bu cumhuriyetin nasıl adlandırılması gerektiğinin tartışmalı olageldiği gözlemlenebilir. 28 Mayıs 1918 tarihinde ilan edilen İstiklal Beyannamesi’nde “Azerbaycan Halk Cumhuriyeti” (AHC) ifadesi üç kere geçmektedir. Buradaki "halk" kelimesi Rusçaya "demokratik" olarak çevrilmiştir. Bunlara rağmen daha sonra devlet kurumlarının resmi yazışma ve mühürlerinde "Azerbaycan Cumhuriyeti” ifadesini tercih ettikleri bilinmektedir. Buna rağmen, Topçubaşı liderliğindeki diplomatik delegasyonunun 1919 Paris Barış Konferansı için (Fransızca ve İngilizce olarak) hazırlamış olduğu memorandumda ise devletin bağımsızlığının "Democratic Republic of Azerbaijan" ismiyle tanınması önerilmekteydi. 28 Nisan 1920'deki Bolşevik işgali sonrasında bu dönemden bahsederken Sovyet tarihçileri, "Müsavat Hükümeti” ifadesini kullanmışlardır. Perestroyka ile birlikte sözkonusu dönemle ilgili yaklaşımlar değişmeye başlamış ve bu çerçevede sayıları artmaya başlayan çalışmalarda "Azerbaycan Demokratik Cumhuriyeti” (ADR) ifadesi kullanılmıştır. Muhtemelen bu ifadenin tercihinde, o esnada toplumdaki demokrasi yokluğu veya eksikliğinin bir etkisi olduğu düşünülebilir. Azerbaycan'ın yeniden bağımsızlığını ilan ettiği 1991'den sonra ise tarihi literatürde hem ADR, hem AHC ve hem de Azerbaycan Cumhuriyeti ifadeleri de eş-değerli olarak kullanılagelmiştir. Günümüzde Azerbaycan tarih yazımında cumhuriyyet dövrü ile 19181920 dönemi kastedilmektedir. Bu yazıda da söz konusu tartışmalardan ve herhangi bir "önyargı”dan bağımsız olarak ADR tercih edilmiştir. Bu arada ADR döneminin, Azerbaycan siyasi tarihinin göreceli en demokratik dönemlerinden biri olduğunu söylemek herhalde yanlış olmazdı.

2 ADR'le ilgili geniş bir bibliyografya çalışması için bkz. Azərbaycan Xalq Cümhuriyyəti 1918-1920: Bibliyoqrafiya, Haz. Ş. Tağıyeva (Bakü: Azerbaycan Milli Kütüphanesi, 2008). Ayrıca, “Azərbaycan Xalq Cümhuriyyəti”, Son güncellenme tarihi 19 Mayıs, 2020, http://axc.preslib.az/az adresli web sayfasına da güncellenmiş bibliyografya listeleri için bakılabilir. 
payesini ziyadesiyle hak eden Topçubaşı'nın dış politika oluşumunda ve bu politikanın pratik düzlemindeki, yani diplomatik faaliyetlerdeki merkezi rolüne işaret edilecektir. Bu çerçevede, Topçubaşı' nın oluşturduğu metinlerin, çağdaş Azerbaycan diplomasi tarihinin temel kaynaklarını teşkil ettiği de belirtilmelidir.

Yazının geliştirmeye çalıştı̆̆ 1 ana fikir, her ne kadar bir devlet tecrübesine tam olarak sahip olmasalar da ADR kurucu kadrolarının dış politikada dönemin şartlarının gerektirdiği çevikliği çok çabuk edindikleri, dış politika ve diplomaside kurumsallaşmayı önceledikleri, devletin tanınması yolunda neredeyse tüm diplomasi araçlarını kullanmaya çalıştıkları hususlarıdır. Tüm bunların da ADR diplomasisinin temsilcisi Topçubaşı'nın eylem ve söylemlerine yansıdığı söylenebilir.

\section{ADR Dış Politikasının Genel Çerçevesi: Parametreler, Tehditler ve Dönemlendirme}

\section{Parametreler}

Çok kısa bir süre varlığını sürdürmesine rağmen ADR' in dış politikada ${ }^{3}$ izlediği politikaların ana hatlarını tespit etmek mümkündür. Bu çerçevede, $\mathrm{ADR}$ dış politikasının temel parametrelerini beş başlık altında toparlamak mümkündür: 1) Varlığının ve bağımsızlığının de facto ve de jure tanınması; 2) Genel güvenliğinin temin edilmesi ve sınırlarının korunması; 3) Müttefik arayışı (özellikle büyük güçler arasında); 4) Komşular ve diğer devletlerle siyasi/ekonomik/ ticari işbirliğini tesis etme; 5) Kafkasya'da konfederasyon fikrini geliştirme. Bu başlıklar ADR'in hemen hemen tüm varlığı süresince gündemde olmuştur.

ADR'in dış politikadaki en temel meselesi, bir devlet olarak varlığının diğer devletler tarafından hem de facto, hem de de jure tanınmasının sağlanması idi. Diğer bir ifade ile, her ne kadar bağımsızlığını ilan etse de, ADR'i meşgul eden başlıca sorun, uluslararası sistem ve özellikle dönemin büyük güçleri tarafından fiilen ve hukuken tanınması idi. Bilindiği üzere, Çarlık rejiminin I. Dünya Savaşı sürerken Şubat 1917 Devrimi ile bir anda çökmesi, Rusya’yı bir belirsizlik ortamına sürüklemiş ve bu ortamda da merkez-çevre ilişkileri iyice gevşemişti. Ekim 1917 Bolşevik Devrimi bu durumu daha da kaotik hale getirmiş ve Güney Kafkasya bölgesi de gittikçe merkezden uzaklaşmıştı. Hatta 1918 başlarında Rusya Kurucu Meclisi'nin daha ilk toplantısında Bolşevik yönetimince ilga edilmesi üzerine bu meclisin Güney Kafkasya'dan olan vekillerinin inisiyatifi ile Tiflis'te Güney Kafkas Konfederasyonu ismiyle bağımsız bir yönetim ilan edilmişti. Fakat bunun akabinde Osmanlı Devleti ile yapılan kısa savaş ve barış

3 ADR dış politikasıyla ilgili şu temel eserlere bakılabilir: Cəmil Həsənov, Azərbaycan Beynelhalk Münasebetler Sisteminde: 1918-1920 (Bakü: Azerneşr, 1993); Азербайджсанская демократическая республика (1918-1920): Внешняя политика (Документы и материаль) [Azerbaijan Democratic Republic 1918-1920: Foreign Policy (Documents and materials)] (Bakü: Izdatel'stvo Azerbaidzhan, 1998); Azerbaycan Halk Cumhuriyeti Ansiklopedisi I-II.cilt (Bakü: 2004) Cemil Hesenli, Azerbaycan Halk Cumhuriyeti'nin Harici Siyaseti, 1918-1920 (Bakü: 2009); Nesib Nesibzade, Azerbaycan Demokratik Respublikasının Harici Siyaseti (Bakü: Qanun, 2011). 
görüşmeleri sürecinde bu bölgedeki meskûn üç büyük topluluk (Azerbaycanlılar, Gürcüler ve Ermeniler), 1918 yılı Mayıs sonlarında bağımsız cumhuriyetler kurduklarını açıklamışlardı. Her ne kadar İttifak devletleri, bu cumhuriyetleri o esnada fiilen tanımış olsa da ve hatta Osmanlı Devleti, 4 Haziran 1918'de bunlarla bir düzine antlaşmalar yapsa da, “büyük harp”te kısa bir süre sonra mağlup olmaları durumu çetrefil bir hale sokmuştu. Zira Bolşevik Devrimi ile birlikte Rusya'nın bir iç savaşa sürüklenmesi, ülkenin iç yapılanması ve uluslararası temsiline dair soruları gündeme getirmişti. Kısacası, bu iç savaş bitmeden I. Dünya Savaşı'nın galipleri olan İtilaf devletleri, Rusya'nın periferisinde bağımsızlık ilan edenlerin varlığını tartışmaya açmaya ve tanımaya mesafeli idiler. Dolayısıyla, Rusya iç savaşının kaderi ve ADR' in tanınma sorunu arasında doğrudan bir ilişki sözkonusu idi. ADR yöneticileri de bu süreçte tüm enerjilerini çeşitli uluslararası platformlarda tanınma sorununu çözmeye yöneltmişlerdi.

ADR dış politikasının ikinci önceliği, ülkenin genel güvenliğinin ve sınırlarının korunmasını temin etmek idi. 23 ay boyunca ADR'in varlığı birkaç kez tehlikeye girmiş ve hatta sınırlarda çatışmalar da meydana gelmişti. ADR ilan edildiğinde ${ }^{4}$ haliyle, sınırları hakkında net değil, genel bir kanaat mevcut idi. Bu sınırlar da, İstiklal Beyannamesi'ne göre, genel olarak Güney Kafkasya'nın doğu ve güney kısımlarını kapsamaktaydı. Elbette ki, buraya çoğunlukla Azerbaycanlıların yaşadığı bölgelerin dahil edildiği anlaşılmaktadır. Bu bölgelerde kamu güvenliğini tesis etmek ve sınırları tahkim etmek, ADR kadrolarını meşgul eden ikinci can alıcı konu idi.

Bununla ilişkili olarak da ADR dış politikasındaki üçüncü öncelik, özellikle büyük veya bölgesel güçler arasında bir müttefik bulma arayışı idi zira o kaotik ortamda böyle bir müttefik, ADR dış politikasındaki ilk iki önceliğin de yerine getirilmesini sağlayabilirdi. Diğer bir deyişle, hem bağımsızlık tanınabilir, hem de varlığını sürdürme garanti altına alınmış olurdu. Bu çerçevede, başlarda Osmanlı Devleti, sonra İngiltere ve akabinde İran’a yönelik bu girişimler vaki olmuştu.

Komşular ve diğer hükümetlerle işbirliği yapmak da genel olarak ADR dış politikasının bir diğer saiki idi. Bilhassa komşu hükümetlerle siyasi, diplomatik, askeri, ekonomik ve ticari işbirliğini tesis etme yönünde çeşitli seviyelerde temaslarda bulunulmuştu. Bu bağlamda, başlarda Osmanlı devleti, sonra Gürcistan ve Kuzey Kafkasya Dağlılar Cumhuriyeti, sonlara doğru ise İran ile muhtelif işbirliği anlaşmaları yapılmıştı. Gerek iç siyasi kırılganlık, gerekse de kaotik dış çevre şartlarından dolayı ADR yöneticilerinin dış politikada üzerinde durdukları ana mevzu, hâliyle işbirliği idi. Hakikaten de ADR kurucuları ve resmi makamlarının bazı komşularının aksine saldırgan ve irredentist değil, savunmacı bir dil ve retorik ile beraber işbirliği ağırlıklı bir söylemi benimsedikleri söylenebilir.

Bununla bağlantılı son olarak, ADR yöneticilerinin işbirliği mevzusunu daha ileri düzeye götürdükleri ve bu çerçevede söz konusu yöneticilerin dış politika söyleminde önemli yer tutan

4 ADR'in kuruluşuna giden yolun detayları ve o süreçte Osmanlı yardımları için bkz. Halil Bal, Azerbaycan Cumhuriyeti'nin Kuruluş Mücadelesi ve Kafkas İslam Ordusu (İstanbul: İdil Yayıncılık, 2010). 
bir diğer husus da, Güney Kafkas hükümetleri arasında bir Kafkasya Konfederasyonu kurma fikri idi. Kafkasya'da konfederasyon kurma düşüncesi, 1918 sonlarından itibaren Azerbaycanlı liderlerin dış politika metinlerine de yansımıştır. Meselâ, Osmanlı devleti nezdinde fevkalade elçi olarak gönderilen Ali Merdan Topçubaşı'nın Kasım-Aralık 1918'de hazırladığı ve diplomatik kaynaklara iletilen uzun bir memorandumda Kafkas Konfederasyonu konusuna ayrı bir bölüm ayrılmıştı. Bölgede işbirliği ve konfederasyon fikri çerçevesinde çeşitli Kafkas konferansları da yapılmıştı. Aralık 1919'da dönemin ADR Dışişleri Bakanı F. Hoyski, Bakü'de bulunan Ermenistan delegasyonuna bölgesel sorunları ancak böyle bir konfederasyon oluşturarak çözebileceklerini telkin etmekte idi. Dahası, 1920 sonrasında muhacerette bulunan ADR yöneticileri, Kafkas Konfederasyonu fikrini savunmaya devam ederek diğer Kafkas muhacir gruplarıyla bu yönde istişare ve görüşmelerine uzun müddet devam etmişlerdir.

\section{Tehditler}

ADR yöneticilerinin, 23 ay boyunca diş politikada dört önemli meydan okumayla karşılaştıkları söylenebilir. Bu tehditleri şöyle sıralamak mümkündür: 1) Bakü Bolşevik Komünü, 2) General Denikin'in Gönüllü Ordusu, 3) Ermenistan'la gerilim ve sinır bölgelerinde lokal savaş, 4) Bolşevik Rusya, Ocak-Nisan 1920. ADR'in varlığına ve sınırlarının güvenliğine doğrudan yönelen bu tehditlerin ilk ikisi bir şekilde bertaraf edilebilmiş, üçüncüsüne karş1 etkin bir karşı koyuş sergilenmiş, fakat sonuncu tehdit ile baş edilememiş ve neticede Bolşevik işgaliyle bu devletin hayatı sona ermişti.

Bilindiği üzere, ADR'in ilanı Tiflis’te yapıldığında başkent olarak seçilen Bakü ile çevresi, iki aydan beridir Bolşeviklerin hakim olduğu Bakü Sovyeti'nin elinde bulunmaktayd1. ${ }^{5}$ On bin kadar silahlı askeri güce sahip Bakü Bolşevik Komünü’ne karşı mücadele etmek 1918 yazında ADR'in ilk görevlerinden biri idi. Bu mücadelede Osmanlı devletinden tam destek alınmış ve “gönüllü” Kafkas İslam Ordusu adıyla hareket eden birlikler üç buçuk ayda Bakü’yü söz konusu unsurlardan temizlemişlerdir.

İkinci büyük tehdit, Rus iç savaşındaki taraflardan birinden gelmişti. Bolşeviklere karşı savaşan General Anton Denikin'in Gönüllü Ordusu, 1919 yılının başından neredeyse sonuna dek ADR üzerinde bir nevi Democles Kılıcı gibi bir tehditte bulunmuştu. "Bölünmez Rusya" fikrini savunan Denikin, eski Rusya topraklarında ortaya çıkan hükümetleri tanımıyordu. Hatta 1919 yazında Kuzey Kafkasya Dağlı Cumhuriyeti'ni de ortadan kaldırmış ve hatta Gönüllü Ordu birlikleri Derbent'i bile ele geçirmişlerdir. Gürcistan ve Azerbaycan'1 tehdit eden Denikin'i, İngilizlerin araya girerek Derbent çevresinde bir demarkasyon hattı çizmesi durdurabilmişti. Akabinde zaten Bolşeviklerden ciddi bir yenilgi alan Denikin de ortadan kaybolmuştu.

ADR'in varlığı boyunca hiç eksik olmayan bir tehdit de komşu Ermenistan'dan gelmişti.

5 ADR'in siyasi tarihiyle ilgili genel bilgi için bkz. Н. Агамалиева, Р. Худиев, Азербайджанская республика: Страницы политической истории 1918-1920 г2. [Azerbaijan Republic: Pages from Political History 19181920] (Bakü: Sabah, 1994) ve Азербайджанская демократическая республика 1918-1920 [Azerbaijani Democratic Republic 1918-1920] (Bakü: Elm, 1998). 
1918-1920 arasında iki hükümet arasında çok ihtilaflı bir ilişki sözkonusu idi. Bölgede oldubittilerle mümkün olduğunca çok toprak ele geçirme hırslarıyla ${ }^{6}$ yanıp tutuşan Erivan'daki hükümet, ADR'e karşı ismi konulmamış bir yıldırma savaşı yürütmekteydi. Özellikle Andranik liderliğindeki silahlı çeteler teşvik edilerek sınır bölgeleri ve Karabağ'ın bazı kısımlarında yerli Müslüman ahaliye karşı etnik temizlik yapılmaktaydı. ADR hükümetleri, bir taraftan Erivan'la müzakere yapmaya, diğer taraftan da ordu birliklerini sınır bölgesine göndererek saldırılara karşılık vermeye çalışıyordu. 1920 başlarından itibaren ise bu çatışmalar Karabağ'ın Ermenistan'la sınır bölgelerinde çok şiddetli bir şekilde devam etmekteydi.

Son tehdit de yine Rus iç savaşının başka bir tarafından, yani Bolşeviklerden gelmişti. 1919'un sonunda Denikin'i mağlup eden Kızıl Ordu birlikleri Kuzey Kafkasya ve Derbent'e kadar gelmişlerdir. 1920 başlarından itibaren de dört ay boyunca ADR'i işgal etme planları yapılmıştı. ADR' in aynı zamanda hem Ermeni birliklere karşı mücadele etmesi, hem de kuzeyden gelen Kızıl Ordu’ya karşı koyması, neredeyse imkansız idi. 25 binlik mevcudu olan Azerbaycan ordusunun gerek eğitim ve tecrübe, gerekse de mühimmat açısından ciddi eksiklikleri vardı. Bu şartlarda iki cephede başarılı bir savunma savaşı verilmesi söz konusu olamazdı. Dahası, Ocak 1920'de her ne kadar ADR, İtilaf devletleri tarafindan de-facto tanınsa da, bu husus, alandaki fiili gerçekliği değiştirememişti ve 28 Nisan 1920'de XI. Kızıl Ordu, işgali başlatmıştı.

\section{Dönemlendirme}

ADR dış politikasında bir dönemlendirme yapılacaksa, sözkonusu dönemin siyasi tarihi de göz önünde tutularak üç aşamadan bahsedilebilir. Bu aşamaları kronolojik olarak şöyle ayırabiliriz: 1) Osmanlı devletinin (tam) himayesi, 2) İngiltere'nin (yarı) himayesi, 3) himayesiz (fiili bağımsız) dönem. Bu aşamaların ilk ikisinde ismi geçen devletlerin değişen derecelerde etkisi ve yönlendirmesinin mevzubahis olduğu söylenebilir. Son aşamada ise, herhangi bir devletin domine edişinden bahsedilmesi zordur.

Bu aşamalara kısaca değinilirse, ilk aşama, Mayıs-Ekim 1918 tarihlerini kapsamakta ve Osmanlı devletinin tam himayesinde geçmiştir. ${ }^{7}$ Kuruluşundan itibaren ilk beş ayda ADR, bir yandan başkent olarak ilan ettiği ama Bolşeviklerin elinde olan Bakü’yü geri almaya, diğer yandan da ülkenin geri kalan kısmında devletin bürokratik yapısını kurmaya ve ayrıca ekonomik sorunları çözmeye çalışmaktaydı. Bu süreçte Osmanlı devleti tarafından de facto ve de jure tanındığ 1 ve hatta 4 Haziran 1918'de bir düzine dostluk ve işbirliği antlaşmaları yapıldığı da belirtilmelidir. Bunun yanında, Kafkas İslam Ordusu ile askeri olarak doğrudan destek verildiği ve siyasi/diplomatik olarak da tam himaye edildiği bilinmektedir. Hatta bu

6 Bu çerçevede Erivan Hükümeti'nin, 1919'da Paris Barış Konferansı'na “Büyük Ermenistan” haritasını sunması ve tüm komşularına yönelik aşırı toprak taleplerinde bulunması hiç şaşırtıcı değildi, bkz. Firuz Kazemzadeh, The Struggle for Transcaucasia (New York: Philosophical Library, 1951).

7 Bu konuda daha geniş bilgi ve belgeler için bkz. Vügar İmanov, Azerbaycan-Osmanlı İlişkileri 1918 (İstanbul: Boğaziçi Üniversitesi Yayınları, 2006). 
himayenin yerel düzeyde iç işlerine karışmaya varmasından duyulan rahatsızlığı iletmek üzere de Ağustos 1918'de Başbakan F. Hoyski tarafından Ali Merdan Topşubaşı'nın İstanbul'a fevkalade yetkili elçi olarak gönderildiği malumdur. Öte yandan, bu kısa dönemde ekonomik sıkıntıları çözmek için ayrıca Osmanlı devletinden mali destek de alınması için girişimde bulunulmuş ve yerel malların kredi karşılığında satışına dair bir antlaşma da hazırlanmıştı. Dahası, yeni ADR paralarının İstanbul'da basılması da arzu edilmekteydi. Fakat Eylül ortalarından itibaren Osmanlı devletinin I. Dünya Savaşı'ndan çekileceğinin işaretlerinin ortaya çıkması, tüm bu projeleri akamete uğratmıştı. Mondros Mütarekesi'nin hemen akabinde Kafkas İslam Ordusu birliklerinin Kasım başlarında ADR topraklarından çekilmesi, Osmanlı etkisini aniden sona erdirmişti. I.Dünya Savaşı'nda Merkez güçler galip gelmiş olsaydı, sözkonusu Osmanlı himayesinin başka türlü sonuçlar da doğurabileceği tahmin edilebilir zira başlıca Osmanlı karar alıcılarından Enver Paşa'nın Azerbaycan'la ilgili farklı projeler düşündüğü anlaşılmaktaydı.

Osmanlı birliklerinin ayrılmasının hemen ertesinde Kasım 1918'de bu sefer İngiliz birlikleri General W. M. Thomson komutanlığgnda Bakü’ye gelmişlerdir. Bu tarihten son İngiliz askerinin Bakü'yü terk ettiği Ağustos 1919'a dek ADR üzerinde İngilizlerin etkisinin veya yarı himayesinin olduğu söylenebilir. ${ }^{8}$ Her ne kadar Thomson ilk başta ADR hükümetini tanımayacağını belirtmiş ise de, daha sonra ADR parlamentosunun çoğulcu bir katılımla açılması ve bu süreçte çeşitli yöneticilerle yapılan temaslar, yerel bazda ADR yönetiminin en makul ve kabul edilebilir bir partner olacağı fikrini doğurmuştu. Bu dokuz aylık dönemde İngilizler, Bakü ve çevresini askeri anlamda kontrol altında tutsalar da, ülkenin sivil yönetimine pek müdahalede bulunmamış ve Bakü'deki ADR hükümetleri ve resmi makamları ile çalışmaya öncelik vermişlerdir. Bu arada, hükümet organları arasında sadece Harbiye Nezareti'nin Gence'de konuşlandığı belirtilmelidir. Son olarak, İngilizlerin Denikin'e karşı 1919 yazında ADR'i diplomatik ve bir manada fiziksel olarak savunur tavır takındıkları yukarıda da vurgulanmıştı. Belki de bu yarı himaye ve İngiliz yetkililerle süreç içinde temaslar, tam o zamanlarda Ankara çevresinde İtilaf devletlerine karşı filizlenmeye başlayan Milli Mücadele güçleri liderlerinin gözünde ADR'in İngiliz yanlısı olabileceği izlenimlerini doğurmuştu. Fakat İngilizler bu süreçte ADR'i ne de facto, ne de jure tanımışlardı.

İngilizlerin de apar topar çekilmeleriyle ADR'in, Ağustos 1919'dan Nisan 1920'ye dek sekiz buçuk aylık tam bağımsız veya himayesiz bir dönemin içine girdiği görülmektedir. Bu dönem, tam bir "güvenlik vakumu"nun yaşandığı bir dönem idi. Çevre bölgelerdeki gelişmeler ile ADR'in uluslararası girişimleri pek olumlu seyretmemekteydi. Bir yandan Bolşevik Rusya'nın Denikin güçlerini yenerek Güney Kafkasya’ya doğru yönelmesi, komşu Ermenistan'la üstükapalı savaşın kızışması ve içeride de özellikle Bakü'de Bolşevik unsurların faaliyetlerini yoğunlaştırması sözkonusu idi. Buna rağmen, bu dönemde dış politikada en önemli kazanım,

8 İngiltere'nin ADR'e bakış1 için bkz. С. 3. Юсифзаде, Азербайджано-британские отночения в начале XX века [Azerbaijani-British Relations at the Beginning of the 20th Century] (Bakü: Tahsil, 2008); ayrıca yayınlanan İngiliz arşiv belgeleri için bkz. Azerbaijan Democratic Republic: Great Britain's Archive Documents, ed. N. A. Maxwell (Bakü: Çaşığlu, 2008). 
10 Ocak 1920 tarihinde ADR' in varlığının İtilaf devletlerince (ABD hariç) de facto tanınması idi. Diğer bir iç açıcı gelişme ise Mart 1920'de İran'la yapılan dostluk anlaşmalarıydı.

\section{Dış Politikanın Pratik Boyutu: Uluslararası İlişkiler ve ADR Diplomasisi}

Yukarıda ifade edilen genel mülahazalar doğrultusunda ADR dış politikasının pratik boyutuna ilişkin de birkaç hususu vurgulamakta fayda vardır. Bu boyutu iki düzlemde ele almak mümkündür. Birincisi, ADR'in öncelikle komşular, sonra bölgesel güçler ve en son da büyük güçler ile kurduğu münasebetlerine ilişkindir. İkincisi ise, sözkonusu diş politika ve ilişkileri yürütürken faydalanılan diplomatik düzlemdir. Diğer bir deyişle, bu düzlem, bizzat ADR diplomasisinin kurumsal yapısı ve enstrümanlarıyla ilgili idi. Bu konuda birçok önemli tarihi kayıt ve çalışma yayınlansa da henüz dört başı mamur teorik/kavramsal ve mukayeseli bir çalışmanın yapılmadığı gözlemlenmektedir.

\section{Bölgesel/Uluslararası Düzeyde İlişkiler}

ADR'in dış politikasında komşularla münasebetlerine bakıldığında, öncelikle kuzeybatısındaki Gürcistan ve kuzeyindeki Kuzey Kafkasya Dağlı Cumhuriyeti ile çok yakın ve hatta müttefik düzeyinde ilişkiler geliştirdiği görülmektedir. Bu üç cumhuriyetin yöneticileri arasında yoğun temaslar sözkonusuydu. Bu üç cumhuriyet arasında pek bir sınır ihtilafı olmaması ve daha ziyade ortak düşmanlarının (meselâ, Denikin) olması, bunları işbirliği yapmaya iten saiklerdendi. Tiflis’te bu hükümetlerin temsilcileri arasında Kafkasya konferansları yapılmıştı. Azerbaycan, bir yandan Denikin'e karşı mücadelede Kuzey Kafkasya Dağlı Cumhuriyeti’ne destek verirken, öbür yandan da yine bu amaçla Gürcistan ile Haziran 1919'da askeri bir ittifak antlaşması imzalamıştı. Her iki hükümet nezdinde de ADR' in temsilcileri bulunmaktaydı. Bu üç hükümetin 1919'da Paris'e gönderdikleri heyetler arasında da çok yakın temas ve istişareler yapılmaktaydi.

ADR'in güney komşusu İran ile ilişkileri problemli başlasa da sonradan çok olumlu yönde gelişmişti. İranlı yetkililer İran'da Azerbaycan ismiyle vilayetlerin olmasından dolayı Azerbaycan ismiyle kurulan bu devleti sırf isminden dolayı tanımak istememekteydiler. 1918 yazında yapılması öngörülen İstanbul Konferansı'na ADR mümessili olarak bulunan Mehmet Emin Resulzade'nin İran sefaretine gönderdiği bir mektubun "böyle bir devleti tanımadıklarından dolayı” geri gönderdikleri vakidir. Ayrıca, Ocak 1919'da İstanbul üzerinden Paris Konferansı'na giderken İran Dışişleri Bakanının, ADR temsilcisi A. M. Topçubaşı’yla gerçekleştirdiği görüşmelerde de benzer bir tutum sergilenmişti. İran'ın 1919'da Paris Konferansı'na sunduğu taleplerde de yeni kurulan Azerbaycan Cumhuriyeti'nin İran'a bağlanması gerektiği, yani toprak iddiaları ileri sürülmüştü. Bunlarla birlikte, 1919 sonlarından itibaren Tahran'ın tutumunda radikal bir değişiklik meydan gelmiş ve ADR'in varlığı tanınmakla kalmamış, bir düzine işbirliği antlaşması da yapılmıştır. Bunun üzerine, ADR, Tahran'a daimi elçi olarak Dışişleri Müsteşarı Adil Han Ziyadhanlı'yı göndermiştir. 
Azerbaycan'ın komşuları arasında o dönemde sadece Ermenistan'la hep gerilimli ilişkilere sahipti ve hatta iki ülke arasında ismi konulmamış bir savaş durumu olduğu da söylenebilir. Bunun da nedeni, Erivan yönetiminin açık bir şekilde irredentist bir politika gütmesi idi. Sınırların henüz netleşmediği bir esnada Erivan, silahlı çeteleri teşvik ederek sınır bölgelerindeki Müslüman nüfuslu köylerdeki ahaliye gözdağı vermeyi amaçlıyor, bunların yerlerini-yurtlarını bırakmalarını istiyordu, aslında bir nevi etnik temizlik politikası yürütüyordu. Ayrıca, Karabağ'ın içindeki Ermeni azınlığı da kışkırtarak ADR yönetimine karşı isyana sevk etmekteydi. Bu duruma ADR hükümetleri önce diplomasi dili ile karşılık vermiş, bu da bir netice vermeyince, ordu birlikleri sınır bölgesine gönderilmişti. 1920 yılının başından itibaren de şiddetli çatışmalar yaşanmıştır.

Osmanlı Türkiye'si siyasi çevreleriyle ilk temaslar, ADR kurulmadan önce Trabzon ve Batum'da yapılan konferanslarda sağlanmıştı. Yine ADR' in bağımsızlık ilanından hemen bir sonraki hafta Batum'da iki hükümet arasında askeri yardımı da içeren bir dostluk antlaşması akdedilmişti. Bu antlaşma, aynı zamanda ADR'in siyasi bağımsızlığının fiilen ve hukuken tanınması demek idi. Fakat Osmanlı Türkiye'si ile münasebetlerin, müteakip altı ayda askeri yardımla desteklenen dostlukla beraber endişe verici bir muğlaklıkta seyrettiği söylenebilir. İlginç bir şekilde, ADR'in istiklali haberi ve bununla ilgili gönderilen telgraf, ne İstanbul basınında yayınlanmış, ne de ilgili devletlere iletilmişti. ${ }^{9} 4$ Haziran' daki dostluk antlaşması resmen ratifiye edilmediği için Osmanlı Türkiye'sinin resmi makamlarının ADR vatandaşlarına nasıl davranacağı sorusu bile o günlerde gündeme gelmişti. ${ }^{10}$ Ayrıca ADR hükümetine İstanbul'dan bu süreçte resmi bir temsilci de atanmamıştı, halbuki Tiflis ve Erivan hükümetleri nezdinde bu tür temsilciler bulunmaktaydı.

Öte yandan, askeri yardım çerçevesinde Nuri Paşa komutasındaki “gönüllü” Kafkas İslam Ordusu'nun teşkil edilmesi ve bu birliklerin Gence'den Bakü’ye doğru harekata başlamasıyla birlikte 1918 yazında ilişkilerin çok yoğunlaştığ bir dönem yaşanmıştı. 16 Haziran 1918'de Tiflis’ten Gence'ye gelen Azerbaycan Milli Şurası o gün kendisini feshetmiş ve F. H. Hoyski başbakanlığında ikinci hükümet kurulmuştu. Henüz 20 günlük bir parlamentonun kendini feshetmesi ve tamamen yeni kişilerden oluşan ikinci bir hükümetin teşkili, elbette ki, o sırada Gence'de bulunan ve tüm askeri meseleleri kontrol eden Nuri Paşa ve onun siyasi işler danışmanı Ahmet Ağaoğlu'ndan bağımsız düşünülemezdi. Hatta burada iç işlerine doğrudan müdahale talimatlarının Nuri Paşa ve Ağaoğlu'na asıl Enver Paşa tarafından verildiği de yüksek ihtimaldir. Tarihi literatürde "Haziran Krizi" olarak bilinen bu olayı zihinlerinde tutan ADR kurucu elitleri, müteakip günlerdeki müdahaleleri de hesaba katarak ülkenin siyasi bağımsızlığı noktasında endişeler taşımaktaydılar. Bu arada, 1918 yazında İstanbul'da düzenlenmesi öngörülen bölgesel bir konferansa M. E. Resulzade başkanlığında bir heyetin gönderildiği belirtilmelidir. Bu heyet ile Gence arasında neredeyse iki ay doğru düzgün bir

9 Bununla ilgili bkz. Vügar İmanov, Azerbaycan-Osmanlı İlişkileri 1918, s. 53-66 ("Azerbaycan İstiklâl Telgrafı Tarihçesi” başlıklı II. Bölüm).

10 Osmanlı Devleti ile Azerbaycan Türk Hanlıklarl Arasindaki Münasebetlere Dair Arşiv Belgeleri: 1575-1918, II. Cilt (Ankara: BOA, 1993), s. 236. 
iletişim kurulamadığı da vurgulanmalıdır. ${ }^{11}$ Haziran sonundan Ekim başına dek faaliyet gösteren heyetin performansı, Gence' deki ADR hükümetince pek tatminkâr bulunamamıştı. ${ }^{12}$ Sonuç olarak, I. Dünya Savaşı'nın bitmesiyle birlikte Osmanlı Türkiye'si ile münasebetler de Ekim 1918 sonrasında seyrekleşmeye ve aktif olmayan bir dönemece girmişti.

ADR'in diğer devlet ve hükümetlerle uluslararası düzeydeki ilişkileri, iki yönden ilerlemekteydi. Birincisi, ilgili devletlerin yerel temsilcileri ile lokal temaslar mevzubahis idi. Bakü'de İtilaf devletlerinin ve eski Rusya topraklarında kurulan bazı hükümetlerin temsilcileri bulunmaktaydı. Bunun yanında, bölgeyi ziyaret eden İtilaf devletlerinin heyetleriyle de müzakereler yapılmaktaydı. Amerikalı General Harbord veya İtalyan Albay Gabba'nın ziyaretleri bunlardan birkaçı idi. Bir diğer kanal ise, 1919'dan itibaren A. M. Topçubaşı başkanlığında Paris’te bulunan ve bir dizi görüşme gerçekleştiren heyetin faaliyetleri idi. Bu heyet, İtilaf devletlerinin üst düzey yetkilileri ve karar alıcılarıyla doğrudan temas kurmak için çalışmaktaydı. Ayrıca, bu heyetin ADR' in varlığı boyunca devleti yurtdışında temsil eden en üst düzeyde bir heyet olduğu, hükümetin uluslararası aktörlerle iletişiminde merkezi bir konumda bulunduğunu ve devletin de facto tanınmasında önemli roller ifa ettiği belirtilmelidir.

\section{ADR Diplomasisinin Kurumsal Yönü}

ADR dış politikasının yürütülmesinde o günün şartlarındaki diplomasinin tüm imkanlarından faydalanılmaya çalışıldığı ve aslında pek çok zorluğa rağmen çok kısa sürede önemli işler başarıldığg ifade edilmelidir. Bu diplomasinin kavramsal ve kurumsal boyutunu, ayrıca kullanılan enstrümanlarını o dönemin diplomasi kültürünü de dikkate alarak değerlendirmek, ADR tarihini de yeniden anlamlandırmak için gereklidir.

Zorlu şartlardan bahsetmişken, öncelikle bu cumhuriyetin kurucularının pek bir devlet ve diplomatik tecrübelerinin olmadığını bilmekteyiz. Bununla birlikte, ADR'in kurucu kadrolarının önemli kısmının yüksek tahsilli olduklarını, bu tahsillerini çarlık Rusya veya Avrupa'nın çeşitli üniversitelerinde aldıklarını biliyoruz ve bu anlamda farklı toplumların içinde yaşama tecrübeleri edindikleri ve birkaç dil konuşabildiklerini varsayıyoruz. Bunların yanında, formel devlet tecrübeleri olmasa da hukuk, siyasi partiler, toplumlararası ilişkiler, basın gibi alanlarda da azımsanmayacak birikime sahip oldukları aşikardır. Asıl bu birikimlerinin diplomasi alanında onlara avantaj sağladığı anlaşılmaktadır. Diğer zorluklara gelince, ADR'in bir devlet olarak henüz tanınmaması, dönemin iletişim araçlarını kullanmadaki eksiklikler, Azerbaycanlılar olarak uluslararası alana toplu olarak daha yeni çıkılması, bu bağlamda uluslararası aktörler ve

11 "Haziran Krizi” düşünüldüğünde, İstanbul-Gence arasındaki bu iletişimin Osmanlı yetkilileri tarafından mı engellendiği; engellenmiş ise, bunun maksatlı yapılıp yapılmadığı da ayrı bir tartışma konusudur zira sözkonusu iletişim, Osmanlı kaynakları ve hatta Kafkas İslam Ordusu üzerinden yapılmaktaydı.

12 Muhtemeldir ki, Resulzade, Osmanlı yöneticilerini (Enver ve Talat paşalar) bizzat tanıdığından ve biraz da onlara hayranlık duyduğundan diplomaside "localitis" olarak bilinen bir duruma da düşmüş idi. "Localitis", daha ziyade görev yaptığı ülkenin görüşlerine daha yakın duran diplomatların pozisyonları için sarfedilen bir terimdir. Resulzade'nin İstanbul'dan gönderdiği diplomatik mektupların orijinalleri ve transkripsiyonları için bkz. İmanov, Azerbaycan-Osmanlı İlişkileri 1918. 
kamuoyu ile tanışıklık ve temasların olmaması gibi faktörler de avantajlı komşularına nazaran normal bir diplomasi yürütmeyi zorlaştırmaktaydı. Hele 23 ay boyunca devletin başkentinin iki kere yer değiştirmesi (geçici başkent Gence'den Bakü’ye geçiş) ve asıl bu sürede beş hükümetin görev yapması ve bu hükümetlerin tamamının koalisyon hükümetleri olması, kısacası iç istikrarın kırılganlığı da normal diplomasiyi kolaylaştıran değil, zorlaştıran etkenler idi.

Kurumsal açıdan bakıldığında, ADR Dışişleri bakanlığı Haziran 1918 sonunda çok az sayıda bir kadro (5-6 kişi) ile Gence'de teşkil edilerek faaliyetine başlamıştı. Ancak asıl Eylül 1918'den itibaren Bakü'ye taşınınca bakanlığın yapısı genişlemiş ve birçok daire (sekreterlik, tercüme, diplomatik, arşiv vs.) tesis edilmiştir. Artık bir sene sonra bakanlığın merkez teşkilatında 60 kişi çalışıyordu. ${ }^{13}$ Azerbaycanlı tarihçi Cemil Hesenli, bakanlığın yurtiçi ve yurtdışı misyonlarında 83 kişinin görev aldığını tespit etmektedir. ${ }^{14}$ Buraya henüz üniversite eğitimi almamış özel katipler ve kuryeler de dahil idi. Bakanlık kadroları arasında sadece Azerbaycanlılar değil, yerel Rus ve diğer etnik grupların mensupları da bulunmaktaydı. Burada ilginç olan bir husus da, bakanlığın kadınlar ${ }^{15}$ istihdam etmesi idi. Bu diplomasi tarihinde ADR'in öncü bir yerinin olduğuna da işaret etmektedir çünkü normalde kadınların diplomasi kurumlarında istihdam edilmesi, II.Dünya Savaşı sonrası yıllara tekabül etmektedir.

ADR'in varlığı süresince resmen dört dışişleri bakanı atanmıştı. ${ }^{16} \mathrm{Bu}$ görevlendirmeler sırasıyla şöyle idi: Mayıs-Ekim 1918 arasında birinci ve ikinci hükümette Mehmet Hasan Hacınski (1875-1931), Ekim-Aralık 1918'de A. M. Topçubaşı (1865-1934); Aralık 1918-Mart 1919 arasında üçüncü hükümette F. H. Xoyski (1875-1920), Mart-Aralık 1919 tarihlerinde dördüncü hükümette Memmed Yusif Caferov (1885-1938) ve Aralık 1919-Nisan 1920 arasında beşinci hükümette yine F. H. Hoyski. Bu görevlendirmelerden sadece Topçubaşı gıyaben atanmış ve görevini fiilen bakan olarak icra edememiştir. Petersburg Teknoloji Enstitüsü’nden mühendis olarak mezun olan Hacınski hariç diğerlerinin ortak noktası, Hukuk fakültelerinde eğitim almaları ve hukukçu tecrübelerine sahip olmaları idi. Topçubaşı, Petersburg Üniversitesi’ni, Hoyski ${ }^{17}$ ise Moskova Üniversitesi'ni birincilikle bitirmişti. Caferov da yine Moskova Üniversitesi’nde tahsilini tamamlamıştı. Bu kişilerin ortak bir diğer özelliğgi, çarlık Rusya’nın parlamentosu Duma'da milletvekili olarak bulunmaları idi. Topçubaşı, I.Duma'da (1906), Hoyski II.Duma'da 1907'de, Caferov ise IV.Duma'da (1912-1917) milletvekili olarak faaliyet göstermişlerdi. $\mathrm{Bu}$ duma tecrübesi, yani parlamentodaki temsil görevleri onların diplomasideki çalışmalarını muhtemelen kolaylaştırmıştı. Dahası, 1917 öncesinde Topçubaşı ile Hacınski Bakü Şehir

13 Rabil Süleymanlı, “Azerbaycan Cumhuriyeti Dışişleri Bakanlığı’nın Oluşturulması ve Kurumsal Yapısı”, Büyük Devletler Kıskacında Bağımsız Azerbaycan 1918-1920, ed. Qiyas Şükürov ve V. Qafarov (İstanbul: IQ, 2010), s. 217-226.

14 Hesenli'nin AHC'nin Harici Siyaseti 1918-1920 çalışmasının 428-435. sayfalarında bu kişilerin kısa biyografileri verilmiştir.

15 Örneğin, G. G. Gafarova Paris Barış Delegasyonu’nda İngilizce tercümanı olarak görev almıştı.

16 Geniş bilgi için bkz. M. Kasımlı ve E. Hüseynova, Azerbaycan Harici İşler Nazırları (Bakü: Adiloğlu, 2003).

17 Hoyski'yle ilgili geniş bilgi için bkz. Z. Bünyadov ve M. Eliyev, Fethali Han Hoyski (Bakü: Şark-Garb, 1997); Feteli Han Hoyski: Heyat ve Fealiyyeti (Sened ve Materiallar) (Bakü: Azerbaycan Neşr., 1998). 
Duması'nda da uzun yıllar bulunmuşlardır. Bu dört kişinin tamamı, 1917'de Rusya Kurucu Meclisi'ne vekil olarak seçilmiş ve akabinde Güney Kafkasya Seymi'nin üyeleri olmuşlardır. Ayrıca, 1917-1918 yıllarında Güney Kafkasya'daki geçici yönetimde bakanlık dahil çeşitli görevler (Topçubaşı hariç) icra etmişlerdir. Diğer diplomatik görevlerine gelince, Topçubaşı'nın Eylül 1918- Mayıs 1919'da İstanbul'da uzun bir süre bulunduğu, Hacinski'nin de Topçubaş1 ile birlikte Aralık 1918'de Paris Barış Delegasyonu'na üye seçildiği (ve bir müddet sonra Paris’ten geri döndüğ̈̈) ve son olarak da Caferov’un Haziran 1918- Mart 1919 tarihleri arasında ADR'in Tiflis'te temsilciliğini yaptı̆̆ı belirtilmelidir.

ADR diplomasisindeki enstrümanlara gelince, genel olarak burada ikili (bilateral) ve çoktaraflı (multilateral) diplomasi, görev üzerine (ad hoc) veya geçici ve mukim temsilci heyetleri, konferans ve memorandum diplomasisi gibi araçların kullanıldı̆̆ı görülmektedir. Özellikle, konferans diplomasisine öncelik verildiği, Tiflis ve Bakü' de Kafkas konferansları düzenlendiği, İstanbul ve Paris'e iki konferans heyeti gönderildiği belirtilmelidir. Birçok üye, danışman ve yardımcı elemanlardan oluşan bu heyetlerden ilki, M. E. Resulzade başkanlığında İstanbul' da Haziran-Ekim 1918 tarihlerinde bulunmuştur. Bu heyetten bazıları daha sonra Paris Barış Konferansına gönderilecek delegasyona dahil edilmişlerdir. Topçubaşı başkanlığındaki Paris Konferansı Delegasyonu ise Aralık 1918'de çok geniş katılımla teşkil edilmiş ve Mayıs 1919'dan 1920'lere dek aktif faaliyet göstermiştir. Mukim temsilcilere gelince, Tiflis, Erivan, İstanbul, Tahran, Kiev, Kırım, Kuban, Zakaspi gibi yerlerde diplomatik temsilciler görevlendirilmişti. ADR'in de facto tanınmasından sonra Mart 1920'de ise 6 ülkede (ABD, İngiltere, Fransa, İtalya, İsviçre ve Polonya) her biri 4-5 kişiden oluşan mukim temsilciliklerin açılması kararı parlamentoda alınmış olsa da, bunu gerçekleştirmek mümkün olamamıştı.

Son olarak, diplomatik kültürün oluşması bakımından yapılan görüşmelerin ayrıntılı tutanaklarının tutulduğu, raporlama işlevinin düzenli yapıldığı, belgelerin birkaç dile tercüme edildiği, merkezde bir bakanlık arşivi oluşturulduğu da not edilmelidir. Mevcut diplomatik kayıtların üstünkörü incelenmesi bile ADR diplomatlarının raporlarının enformasyon, bilgi, analiz ve öngörü yönünden kısa sürede profesyonel bir düzeye ulaştığını göstermektedir.

\section{III. “Baş Diplomat”: Ali Merdan Topçubaşı (1865-1934)}

\section{7 Öncesinde Topçubaşı'nın Toplumsal Rolü}

ADR'in tüm bu dış politika ve diplomasi süreçlerinin merkezinde yer alan A. M. Topçubaşı'ya daha yakından bakmakta vardır. Topçubaşı, dış politika söylemine katkıları, üstlendiği çeşitli dış görevleri ve diplomatik faaliyetleriyle ADR' in “baş diplomatı” sayılabilirdi. Onun çabalarıyla ADR diplomasisi önemli mesafeler kat etmişti.

Aslında Topçubaş ${ }^{18} 1917$ öncesinde Azerbaycan toplumunun liderlerinden biri olup pek çok

18 Topçubaşı'nın detaylı biyografisi için bkz. Vügar İmanov, Ali Merdan Topçubaşı (1865-1934) (İstanbul: Boğaziçi Üniversitesi Yayınları, 2003) ve Cemil Hesenli, Tarihi Şahsiyetin Tarihi: Ali Merdan Bey Topçubaşov (Bakü: ADA, 2013). 
alanda faaliyet gösteren bir aydın idi. Hayatının ana başlıklarını vermek bile onun nasıl bir lider aydın olduğunu gösterecektir. 1865 'te Tiflis'te doğan Topçubaşı, burada liseyi bitirdikten sonra Petersburg Üniversitesi'nde hukuk tahsili almıştı. Bunun ardından Tiflis’e dönen Topçubaşı, bir müddet adliye ve eğitim kurumlarında çalışmıştı. 1894'ten sonra da Bakü'ye taşınarak Zeynelabidin Tağıyev'in satın aldığı Kaspi gazetesinde uzun yıllar editörlük yapmıştı. ${ }^{19}$ Rusça yayınlanan Kaspi, Azerbaycanlıların 1898'den 1905'e kadar Bakü'de neşredilen tek yayın organı idi. Basındaki faaliyetlerinin yanı sıra bu süreçte Topçubaşı, Bakü Duması'na seçilerek şehirdeki yerel yönetimin çalışmalarına da katılmıştı.

Öyle anlaşılıyor ki, 1905 Rus devrimine gelindiğinde Topçubaşı gerek yerel, gerek Kafkasya, gerekse Rusya düzeyinde özellikle de Müslüman ve Türk kökenli azınlıklar arasında çok iyi tanınan bir ismi idi. Bu nedenledir ki, 1905-1917 arasında yapılan Rusya Müslümanlarının beş kongresinin de düzenlenmesinde öncülük etmiş, 1906' da yine bu topluluk içinde ilk resmi siyasi parti olan Rusya Müslümanları İttifakı Partisi'nin kurucusu ve tüzügünün hazırlayanı olmuştur. Bunun yanında, yine aynı yıl toplanan I.Duma'da Müslüman Fraksiyonu'nun başkanlığını da yapmıştı. Kısacası, Topçubaşı bu süreçte hem Azerbaycan toplumunu, hem de Rusya Müslümanlarını siyasi alanda temsil eden bu toplulukların haklarını savunan ve sorunlarını gündeme getiren bir lider figüre dönüşmüştü. O, Kırımlı ceditçilerden İsmail Bey Gaspıralı'dan Polonyalı milletvekillerine, Tatarların önde gelenlerinden Kafkasya ve Türkistan'ın aydınlarına pek çok kişi ile yakın ilişkiler geliştirmişti.

1917'nin sanc1lı günlerinde de yine Topçubaşı, Bakü'de Azerbaycan toplumunun öncüllerinden biri olarak siyasi ve sosyal olayların merkezinde yerini almıştı. Bu sırada Rusya Kurucu Meclisi'ne ve sonra Kafkasya Seymi'ne seçilmiş ve Bakü'de örgütlenme faaliyetlerini koordine etmişti. 31 Mart 1918'de Bakü'de Bolşeviklerin ve Ermenilerin yaptığı katliamlar sonrasında ise derdest edilerek Ağustos ayına kadar hapishanede kalmıştı.

\section{ADR Diplomasisinde Topçubaşı'nın Merkezi Rolü}

Topçubaşı, her ne kadar ADR'in kuruluşunun 28 Mayıs 1918'te ilanı esnasında hapishanede olsa da, Haziranda kurulan ikinci Hoyski kabinesine gıyabında devlet bakanı olarak atanmıştı. Ağustos 1918'de hapisten kurtulur kurtulmaz ADR' in devlet kuruculuğu çalışmalarına katılmış ve ilk diplomatik faaliyetine Osmanlı devleti nezdinde fevkalade yetkili elçi olarak başlamıştı. 1918 Eylül sonu İstanbul'a varabilen Topçubaşı'nın asıl misyonu, Osmanlı yöneticilerinin ADR'in geleceğine yönelik yaklaşımlarını netleştirmek idi.

Ekim başından itibaren İstanbul'da diplomatik görevini icra etmeye başlayan Topçubaşı, dört ay içinde 30 kişi ile 37 görüşme gerçekleştirmiş ve bu görüşmelerin detaylı tutanaklarını da hazırlamıştı. ${ }^{20} \mathrm{O}$, esasen başlangıçta Osmanlı üst düzey yöneticileri ve Mondros Mütarekesi’nden

19 Bu arada, Topçubaşı'nın, Azerbaycan dilinde ilk gazeteyi çıkaran Hasan Bey Zerdabi’nin kızı Peri Hanımla evli olduğunu da not etmek gerekir.

20 А. М. Топчибашев: Дипломатические беседы в Стамбуле [Dipomatic Conversations in Istanbul], haz. A. Paşaev ve V. Agaev (Bakü: Ergün, 1994). 
sonra da İtilaf devletlerinin temsilcileri ile çeşitli temaslarda bulunmuştu. Topçubaşı'nın bu temaslarındaki maksadı, ADR'in bağımsız bir hükümet olarak var olduğu fikrini yaymak ve bağımsızlığın tanınması için lobi yapmak idi. Bu amaçlarla Topçubaşı, detaylı bir memorandum da hazırlamıştır. Bu memorandumun Azerbaycan'la ilgili uluslararası aktörlere sunulmuş ilk kapsamlı diplomatik metin olduğunu belirtmek gerekiyor. Bu memorandum Ocak 1919'da Azerbaycan'ın Teşekkülü ismiyle yayınlanarak yerel kamuoyuna da Osmanlıca olarak sunulmuştu. ${ }^{21}$ Daha sonra bu metin genişletilerek Paris Konferansı katılımcılarına da başlıca memorandum olarak iletilmişti. Topçubaşı, İstanbul'da bulunduğu sürede Ziya Gökalp, Fuat Köprülü gibi birçok ileri gelen kişilerle de temas halinde idi. Ekim 1918'de Topçubaş1, görüşmeleri daha yetkin yapmak üzere gıyabında Dışişleri bakanı olarak atanmıştır. Aralık ayında ise, yine gıyabında ADR parlamentosunun başkanı seçilmiş ve akabinde devlet başkanı sıfatıyla Paris Barış Konferansı'na gönderilecek delegasyonun başına getirilmişti. Bu delegasyona, Azerbaycan'la ilgili her türlü görüşmeleri yürütmek ve antlaşmalar yapmak üzere son derece geniş yetkiler verilmişti.

İstanbul'da oldukça yoğun geçen diplomatik temaslardan sonra Topçubaşı, Mayıs 1919'dan itibaren Paris'te Azerbaycan'ı temsil eden heyetin başında üst düzey sayısız görüşmeler yapmıştı. Topçubaşı, Paris'e gelir gelmez çok kısa sürede buradaki atmosfere adapte olmuş ve çeşitli diplomatik inisiyatiflerle diğer benzer heyetlerden farklılaşmaya çalışmıştı. Örneğin, 28 Mayıs 1919'da, yani ADR'in kuruluşunun birinci yıldönümüne tevafuk eden bir günde ABD Başkanı W. Wilson'la görüşme gerçekleşmişti. Bunun yanında, eski Rusya topraklarında kurulan hükümetlerin delegasyonları ile çok yakın temaslar sağlanmıştı. Azerbaycan'ın bağımsızlığının tanınması için Topçubaşı'nın başında bulunduğu Paris Delegasyonu tarafından önemli miktarda tanıtıcı ve bilgilendirici materyal de hazırlanmıştı. ${ }^{22}$ Bu materyaller, hem Fransa' da, hem de Avrupa'da lobi faaliyetleri için de kullanılmaktaydı. Topçubaşı, ABD'de bile Azerbaycan lehine lobi yaptırmak için girişimlerde bulunmuştu. Bunun yanında, Topçubaşı, başında bulunduğu delegasyonun faaliyetlerini ve mevcut durumu değerlendiren düzenli raporlar yazmıştır. Öyle ki, Mart-Aralık 1919 tarihleri arasında Bakü’ye 11 mektup ve bir düzine ek materyal göndermişti. ${ }^{23}$ Tüm bu raporların modern Azerbaycan diplomasi tarihinin temel kaynaklarını oluşturduğu söylenebilir.

Paris'teki uzun diplomatik faaliyetlerin sonucunda ve Rusya iç savaşındaki durumun da değişmesi ile İtilaf devletleri temsilcileri, 10 Ocak 1920 tarihinde ADR'i de facto tanıma kararı

21 A. M. [Topçubaş], Azerbaycan'ın Teşekkülü (İstanbul: Ahmediye Matbaacılık Şirketi, 1918).

22 Bu yayınlardan bazıları şunlardı: 1) Claims of the Peace Delegation of the Caucasian Azerbaidjan presented to the Peace Conference in Paris, 2) Economic and Financial Situation of Caucasian Azerbaidjan to the Peace Conference in Paris, 3) Composition Antropologique et Ethnique de la Population de l'Azerbaidjan du Caucase, 4) La Première Republique Musulmane: L'Azerbaidjan, 5) L'Azerbaijan en Chiffres, 6) Bulletin d'Information de l'Azerbaidjan (Eylül 1919- Nisan 1920, toplam 12 sayı). Bu yayınlardan ilkinin Azerbaycan diline çevrilmiş versiyonu için bkz. Azerbaycan Paris Sülh Konfransinda 1919-1920, terc. V. Guliyev (Bakü: Ozan, 2008).

23 Bu mektupların yedisi için bkz. А. М. Топчибашев: Дипломатические беседы в Стамбуле [Dipomatic Conversations in Istanbul], haz. V. Guliyev (Bakü: Azerneşr., 1998). 
almışlardır. Bu süreçte Topçubaşı, İtilaf devletlerinin üst düzey yetkilileri ile pek çok görüşme yapmış ve bu görüşmelerde Bakü’ye askeri, maddi ve mali yardımları müzakere etmişti. Netice itibariyle, Bolşeviklerin ilerlemesini durdurma mümkün olamamış ve 28 Nisan'da ADR'in işgaline başlanmıştı. Bu tarihten sonra da Topçubaşı bir süre daha durumu İtilaf devletleri nezdinde müzakere etmek üzere bazı uluslararası konferanslara katılmış ve Avrupa basınına sözkonusu işgali protesto eden mesajlar vermişti.

1920'den sonra artık Topçubaşı'nın muhaceret hayatı başlamıştı. Yurtdışında ADR' in tek üst düzey yetkili delegasyonunun başkanı olarak muhaceret ortamında ADR'i temsil etmeye çalışmış, benzer durumdaki delegasyon ve gruplarla yazışmalarına devam etmiş, Azerbaycanlı muhacirleri mobilize etmeye gayret etmiş ve ömrünün sonuna dek Azerbaycan'ın bağımsızlı̆̆ idealini savunmuştu. Ve 5 Kasım 1934'te vefat eden Topçubaşı, geriye Azerbaycan tarihinde önemli bir yer tutacak zengin siyasi ve diplomatik faaliyetler mirası bırakmıştı. ${ }^{24}$

\section{Sonuç}

Yaklaşık iki senelik süre içinde ADR, bağımsızlığının fiili ve hukuki açıdan tanınması, kendi varlığının/bekasının ve sınırlarının korunması, komşuları ve bölge devletleriyle çeşitli işbirlikleri geliştirmesi ve ayrıca dünya siyaset sahnesinde etkin olan uluslararası aktörlerle iletişim kurmak adına yoğun bir çaba içine girmiştir. Bu bağlamda, dış politikada pek çok zorlu meydan okumalar ve tehditlerle karşı karşıya kalmalarına rağmen ADR yöneticilerinin tüm bunları bertaraf etmeye yönelik kapsamlı hazırlıklar yaptıkları ve ciddi çabalar içine girdikleri söylenebilir. Dahası, yeni kurulmuş bu devletin dış politikadaki kadrolarının da pek bir diplomatik tecrübelerinin olmadığı, ama buna rağmen çok kısa sürede yetkililerin hem uluslararası siyasetin işleyişine, hem de diplomasinin gerekliliklerine hızlı bir şekilde adapte oldukları görülmektedir.

ADR'in diş politika ve diplomasisindeki yoğun gündeminin tam merkezinde de üstlendiği hem iç (devlet bakanı, dışişleri bakanı, parlamento başkanı), hem de dış politika (İstanbul'da fevkalade sefir ve Paris Barış Konferansı Delegasyonu başkanlığı) görevleriyle Ali Merdan Topçubaşı'nın bulunduğu ileri sürülebilir. Topçubaşı, ADR dış politikasının belirlenmesinde ve uluslararası arenada uygulanmasında başat bir konumda bulunmaktadır. Diğer bir ifadeyle, dış politikanın hem yapımcısı, hem de uygulayıcı olarak müstesna bir yere sahiptir. Özellikle 1918 Ağustos'undan gönderildiği İstanbul'da ve akabinde Paris'te ADR'in yurtdışındaki en yetkili ağzıdır. Bu bağlamda, yurtdışına gönderilen en uzun ömürlü delegasyonun da başında bulunmuştur. 1920 sonrasında muhaceret yıllarında da Avrupa'da çeşitli düzeylerde temaslarına devam etmiştir. Topçubaşı'nın çok yönlü diplomatik faaliyeti, ADR'in uluslararası aktörlerle

24 Topçubaşı'nın arşivinden yayınlanmış eserler için bkz. А. М. Топчибаши: Документы из личных архивов 1903-1934 22. [A. M. Topchibashi: Documents from Private Archives 1903-1934], ed. S. Iskhakov (Moskova: Izd-vo Sotsial'no-Politicheskaia Mysl', 2012); А. М. Топчибаши: Парижский архив 1919-1940 в четырех momax [A. M. Topchibashi: The Paris Archive, 1919-1940 in 4 volumes], ed. G. Mamulia ve R. Abutalibov (Moskova: Khudojestvennaia Literatura, 2016). 
iletişimini kolaylaştırmış, devletin kimliğinin uluslararası kamuoyunda tanıtılmasına ve bağımsızlığının tanınmasına yardımcı olmuştur. Topçubaşı’nın bu süreçte ürettiği diplomatik metinler, çağdaş Azerbaycan diplomasi tarihinin temel metinleri addedilebilir. Son olarak, tüm bu diplomatik mirası dikkate alındığında Topçubaşı'yı çağdaş Azerbaycan diplomasisinin kurucusu olarak nitelemek de pek yanlış olmazdı.

Hakem Değerlendirmesi: Dış bağımsız.

Çıkar Çatışması: Yazar çıkar çatışması bildirmemiştir.

Finansal Destek: Yazar bu çalıșma için finansal destek almadığını beyan etmiștir.

Peer-review: Externally peer-reviewed.

Conflict of Interest: The author has no conflict of interest to declare.

Grant Support: The author declared that this study has received no financial support.

\section{Kaynakça/References}

A. M. [Topçubaşı], Azerbaycan’ın Teşekkülü (İstanbul: Ahmediye Matbaacılık Şirketi, 1918).

A. М. Топчибашев: Дипломатические беседы в Стамбуле [А. M. Topchibashi: Dipomatic Conversations in Istanbul], haz. A. Paşaev ve V. Agaev (Bakü: Ergün, 1994).

A. М. Топчибаши: Документы из личных архивов 1903-1934 г2. [A. M. Topchibashi: Documents from Private Archives 1903-1934], ed. S. Iskhakov (Moskova: Izd-vo Sotsial'no-Politicheskaia Mysl', 2012).

A. М. Топчибаши: Парижский архив 1919-1940 в четырех томах [A. M. Topchibashi: The Paris Archive, 1919-1940 in 4 volumes], ed. G. Mamulia ve R. Abutalıbov (Moskova: Khudojestvennaia Literatura, 2016).

Агамалиева, Н., Худиев, Р., Азербайджанская республика: Страницы политической истории 1918-1920 z2. [Azerbaijan Republic: Pages from Political History 1918-1920] (Bakü: Sabah, 1994).

Azerbaijan Democratic Republic: Great Britain's Archive Documents, ed. N. A. Maxwell (Bakü: Çaş10ğlu, 2008). Азербайджанская демократическая республика (1918-1920): Внешняя политика (Документь и материаль) [Azerbaijan Democratic Republic 1918-1920: Foreign Policy (Documents and materials)] (Bakü: Izdatel'stvo Azerbaidzhan, 1998).

Азербайджанская демократическая республика 1918-1920 [Azerbaijani Democratic Republic 1918-1920] (Bakü: Elm, 1998).

Azerbaycan Halk Cumhuriyeti 1918-1920: Bibliyografya, haz. Ş. Tağıyeva (Bakü: Azerbaycan Milli Kütüphanesi, 2008).

Azerbaycan Halk Cumhuriyeti Ansiklopedisi I-II.cilt (Bakü: 2004).

Azerbaycan Halk Cumhuriyeti Bibliyografyası, http://axc.preslib.az/

Azerbaycan Paris Sülh Konfransında 1919-1920, terc. V. Guliyev (Bakü: Ozan, 2008).

Bal, Halil, Azerbaycan Cumhuriyeti'nin Kuruluş Mücadelesi ve Kafkas İslam Ordusu (İstanbul: İdil Yayıncılık, 2010).

Bünyadov, Z. ve Eliyev, M., Fethali Han Hoyski (Bakü: Şark-Garb, 1997); Feteli Han Hoyski: Heyat ve Fealiyyeti (Sened ve Materiallar) (Bakü: Azerbaycan Neşr., 1998). 
Hesenov, Cemil, Azerbaycan Beynelhalk Münasebetler Sisteminde: 1918-1920 (Bakü: Azerneşr, 1993).

Hesenli, Cemil, Azerbaycan Halk Cumhuriyeti'nin Harici Siyaseti, 1918-1920 (Bakü: 2009).

Hesenli, Cemil, Tarihi Şahsiyetin Tarihi: Ali Merdan Bey Topçubaşov (Bakü: ADA, 2013).

Kazemzadeh, Firuz, The Struggle for Transcaucasia (New York: Philosophical Library, 1951).

İmanov, Vügar, Azerbaycan-Osmanlı İlişkileri 1918 (İstanbul: Boğaziçi Üniversitesi Yayınları, 2006)

İmanov Vügar, Ali Merdan Topçubaşı (1865-1934) (İstanbul: Boğaziçi Üniversitesi Yayınları, 2003)

Kasımlı, M. ve Hüseynova, E., Azerbaycan Harici Işler Nazırları (Bakü: Adiloğlu, 2003).

Nesibzade, Nesib, Azerbaycan Demokratik Respublikasının Harici Siyaseti (Bakü: Qanun, 2011).

Osmanlı Devleti ile Azerbaycan Türk Hanlıkları Arasındaki Münasebetlere Dair Arşiv Belgeleri: 1575-1918, II.Cilt (Ankara: BOA, 1993).

Süleymanlı Rabil, “Azerbaycan Cumhuriyeti Dışişleri Bakanlı̆̆ı’nın Oluşturulması ve Kurumsal Yapısı”, Büyük Devletler Kıskacında Bă̆ımsız Azerbaycan 1918-1920, ed. Qiyas Şükürov ve V. Qafarov (İstanbul: IQ, 2010), s. 217-226.

Юсифзаде, С. 3., Азербайджано-британские отношения в начале XX века [Azerbaijani-British Relations at the Beginning of the 20th Century] (Bakü: Tahsil, 2008). 
